\title{
Московский инженерно-физический институт
}

Глазков А. А. Высшиегармоники волны $T M$ в ди аdрагми рованном волноводе линейного электронного у с к о р.и теля. Научный руководитель д. ф.-м. н. проф. П. А. Рязин. Защита состоялась 22 декабря 1958 г. Официальные оппоненты: д. фм. н. проф. П. Е. Краснушкин, к. т. н. Я. М. Туровер.

В работе поставлена и в первом прибліжении решена задача о влиянии на работу линейного электронного ускорителя высших гармонических волн, которые неизбежно сопутствуют основной ускоряющей волне в днафрагмированном волноводе. Рассмотрены физнческие принины возникновения высших гармоник, их свойства и разработана теория, позволяющая в..тислить функцию распределения амплитуд гармоник и отно- 
сительную парциальную мощность основной волны в зависимости от параметра нагрузки $a / \lambda$ и фазовой скорости $\beta$. Показано, что в результате расхода высокочастогной мощности на высшие гармоники волны $T M$ амплитуда основной ускоряющей волны уменьшается на величину до $30 \%$. Это уменьшение эффективного потока высокочастотной энергии должно быть учтено при конструировании линейного ускорителя, наряду с расходом мощности па ускорение частиц (нагрузка током) и на поверхностные токи в волноводе (затухание). Приведены численные результаты расчетов в виде удобных для инженерного пспользования графиков. Результаты расчетов проверены эксперн. ментально при помсщи спениально разработанного метода рсактивного зонда. Анализ работы нашболее известных действующих линейных ускорителей показывает, что учет гармоник хорошо объясняет недобор проектшой энергии электронов, наблюдаемый на этих машинах.

С обенин Н.П. Разработка методов экспериментальной проверки фазовой скорости в волноводелинейного эл скт ронного ускорителя. Научный руководитель д. ф.-м. н. проф. П. А. Рязин. Защита состоялась 22 декабря 1958 г. Официальные оппоненты: д. т. н. Л. Н. Лошаков, д. т. н. Б. К. Шембель.

Недостаточная точность существующих методов расчета размеров диафрагмированного волновода и неизбежные ,погрешности при его изготовлении приводят $\mathrm{K}$ отклонениям фазовой скорости от выбранных оптимальных значений. Отсюда следует необходимость измерений с целью экспернментальной проверки фазовой скорости. Такая проверка не вызывает затруднений в волноводе с постояной структурой. Однако измерение фазовой скорости в группирователе представляет значительные трудности даже на виде колебаний $\pi / 2$. В работс дано подробное описание методов, разработанных для решения этой задачи: метода фазометра и метода отражающего поршня. Для различных измерений на диафрагмнрованиом волноводе может оказаться полез. ной предложенная в работе методика подбора нсотражающих нагрузок, обеспечивающих в волноводе режим бегущей волны. Приводятся экспериментальные параметрические кривые, которые позволяют определить размеры диафрагмированного волповода с точностыо, превышающей точность нзвестных в настоящее время теоретических методов. Эксперименталыные данные, получениые на действующи линейных ускорителях, показывают хорошее совпадение с развитыми в работе положениями.

Доц. И. П. Степаненко 